\title{
HUBUNGAN PENGETAHUAN IBU BAYI TENTANG POSYANDU DENGAN FREKUENSI KUNJUNGAN IBU DAN BAYI DI POSYANDU \\ (Studi di Desa Kemlagilor Kecamatan Turi, Kabupaten \\ Lamongan tahun 2016)
}

\author{
Siti Aisyah \\ *Dosen Program Studi D III Kebidanan Universitas Islam Lamongan
}

\begin{abstract}
ABSTRAK
Rendahnya kunjungan masyarakat ke pelayanan kesehatan kemungkinan dikarenakan faktor-faktor social budaya, tingkat pendidikan, umur, tingkat kecerdasan, pekerjaan, advokasi, kondisi manusia, motivasi, geografi, transportasi, sikap dan perilaku. Tujuan penelitian ini adalah Untuk mengetahui hubungan antara pengetahuan ibu bayi tentang posyandu dengan frekuensi kunjungan ibu dan bayi di posyandu di Desa Kemlagilor, Kecamatan Turi, Kabupaten Lamongan.

Jenis penelitian ini adalah observasional analitik dengan pendekatan cross sectional Jumlah sampel 24 responden, diambil secara Simple Random Sampling. Variabel bebasnya adalah pengetahuan ibu bayi tentang posyandu, sedangkan variabel tergantungnya adalah frekuensi kunjungan ibu dan bayi di posyandu.

Dari hasil penelitian didapatkan data $76,96 \%$ ibu bayi yang melakukan kunjungan ke posyandu. Hasil nilai koefisien phi 0,04. Karena nilai $\alpha: 0,05$ dan nilai dari koefisien phi adalah 0,04 berarti $\alpha<\mathrm{p}(0,04<0,05)$, artinya $\mathrm{H}_{0}$ ditolak yaitu terdapat hubungan antara pengetahuan ibu bayi tentang posyandu dengan frekuensi kunjungan ibu dan bayi di posyandu.

Kesimpulan pembahasan terdapat hubungan pengetahuan ibu bayi tentang posyandu dengan frekuensi kunjungan ibu dan bayi di posyandu. Oleh karena itu ibu bayi sebaiknya lebih memahami tentang pentingnya melakukan kunjungan ke posyandu.
\end{abstract}

Kata Kunci : Pengetahuan tentang posyandu, Frekuensi kunjungan di posyandu

\section{PENDAHULUAN}

Dalam rangka melaksanakan pembangunan kesehatan masyarakat Desa (PKMD) di Indonesia kita melaksanakan posyandu atau pos pelayanan terpadu. Melalui posyandu masyarakat dapat memperoleh pelayanan dasar paripurna keluarga berencanakesehatan. Posyandu sangat penting dalam pengembangan sumber daya manusia sejak dini. Dengan adanya posyandu diharapkan penurunan angka kematian bayi dan angka 
kesuburan dapat dipercepat (Depkes RI, 1988).

Pos Pelayanan terpadu atau Posyandu merupakan bagian dari pembangunan kesehatan yang diprogramkan oleh pemerintah dimana sasarannya adalah pembangunan kesehatan untuk mencapai keluarga kecil bahagia dan sejahtera yang dilaksanakan oleh keluarga, bersama masyarakat dengan bimbingan dari petugas kesehatan setempat. Kegiatannya yang dimulai dari proses pendaftaran, penimbangan, pengisian KMS, pemeriksaan balita, pemberian imunisasi, penyuluhan, dan sederet kegiatan yang terdapat dalam posyandu.

Dari hasil posyandu di Indonesia, partisipasi posyandu masyarakat Indonesia yang awalnya diperkirakan mencapai $60-70 \%$ menurun menjadi $30-40 \%$ (Adisasmito, 2007). Di jawa timur kunjungan posyandu mencapai $87 \%$ (Data laporan Dinkes Jatim tahun 2006). Di Kabupaten lamongan mencapai $\quad 75,74 \%$ sementara targetnya adalah $85 \%$ (Laporan bulanan pelayanan gizi tingkat kabupaten). Di Puskesmas Turi mencapai $82,1 \%$ sementara targetnya adalah $85 \%$ (Laporan bulanan pelayanan posyandu kecamatan turi). Di Desa Kemlagilor kunjungannya mencapai $70 \%$, sementara target yang harus terpenuhi adalah $85 \%$. Dari data tersebut menunjukkan kurangnya kunjungan para ibu bayi untuk datang ke Posyandu.

Masih rendahnya kunjungan masyarakat ke pelayanan kesehatan kemungkinan dikarenakan faktorfaktor social budaya, tingkat pendidikan, umur, tingkat kecerdasan, pekerjaan,advokasi, kondisi manusia, motivasi, geografi, transportasi, sikap dan perilaku masyarakat.

Dampak yang terjadi bila masyarakat tidak melaksanakan kunjungan ke Posyandu diantaranya adalah tidak terdeteksinya penyakit yang menyerang pada bayi, sehingga kesehatan bayi menurun, angka kematian bayi akan semakin meningkat, yang pada akhirnya akan menghambat pembangunan dan kemajuan negara dan bangsa. Karena seluruh bayi yang ada saat ini adalah aset bangsa di masa depan nanti.

Upaya untuk meningkatkan partisipasi para ibu sehingga aktif melaksanakan kunjungan ke Posyandu adalah dengan cara meningkatkan pengetahuan ibu-ibu akan pentingnya manfaat berkunjung ke Posyandu dengan segala kegiatan di dalamnya, memberikan penyuluhan pada saat acara pengajian, PKK, peran penting dari para kader, kades, camat, bupati, dan terpenting adalah kebijakan yang ada dari pemerintah.

\section{TUJUAN PENELITIAN}

Mengetahui Hubungan Pengetahuan Ibu bayi dengan keaktifan Kunjungan Bayi di Posyandu desa Kemlagilor kecamatan Turi kabupaten Lamongan.

\section{METODE PENELITIAN}

\section{Desain Penelitian}

Jenis penelitian ini adalah penelitian analitik observasional yaitu melakukan pengamatan yang mana peneliti tidak memberikan suatu perlakuan pada obyek yang diteliti. (Nursalam, 2008). 
Sedangkan pendekatan yang digunakan adalah cross sectional yaitu jenis penelitian yang menekankan pada waktu pengukuran atau observasi data variabel independent dan dependent hanya satu kali pada satu saat untuk mengetahui dinamik korelasi (Nursalam, 2008).

\section{Waktu dan Tempat}

Penelitian ini dilakukan pada bulan Januari sampai dengan Agustus tahun 2016 di posyandu desa Kemlagilor, Kecamatan Turi Kabupaten Lamongan.

\section{Populasi dan Sampel}

Populasi adalah keseluruhan subjek penelitian (Arikunto S, 2002). pada penelitian ini populasinya adalah ibu bayi di desa kemlagilor, kecamatan turi, kabupaten lamongan sebanyak 25 responden.

Besar sampel adalah anggota yang akan dijadikan sampel. (Nursalam, 2008). Besar sampel berdasarkan jumlah sampel apabila populasi kecil atau lebih kecil dari 1.000 , dapat menggunakan formula yang lebih sederhana yaitu dengan menggunakan rumus, (Nursalam, 2008) :

$$
\mathrm{n}=\frac{\mathrm{N}}{1+\mathrm{N}\left(\mathrm{d}^{2}\right)}
$$

Keterangan:

$\mathrm{n}$ : sampel

$\mathrm{N}$ : populasi

d : tingkat signifikan $(0,05)$

\section{Teknik Pengambilan Sampel}

Teknik sampling yang digunakan dalam penelitian ini adalah probability sampling dengan teknik simple random sampling (acak). Dengan cara yaitu penyusunan dafttar populasi, menghitung besar sample dan wilayah kerja, membuat nomer undian, mengambil undian sebanyak hasil perhitungan sampel.

\section{Cara Pengumpulan Data}

Pengumpulan data adalah suatu proses pendekatan kepada subjek dan proses pengumpulan karakteristik subjek yang diperlukan dalam suatu penelitian (Nursalam, 2008). Data dikumpulkan melalui kuesioner pada ibu nifas di BPS Yuliana Kabupaten Lamongan yang memenuhi kriteria inklusi.

\section{Pengolahan dan Analisa Data Teknik Pengolahan Data}

Data yang telah diperoleh kemudian dilakukan pengolahan sebagai berikut:

1. Pemeriksaan Data (Editing)

Editing adalah kegiatan yang bertujuan untuk meneliti kembali apakah isian pada angket atau kuesioner dan checklist sudah cukup baik sehingga upaya menjaga kualitas data agar dapat di proses lebih lanjut (Budiarto, 2002).

2. Pengkodean (Coding)

Coding

adalah pengklasifikasian jawaban menurut kriteria tertentu yang ditandai dengan kode tertentu berapa angka, sehingga menjadi bentuk lebih ringkas yang akan mempermudah saat tabulasi dan analisa data (Budiarto, 2002). 
1. Pengetahuan

1) Baik :2

2) Cukup :1

3) Kurang :0

2. Frekuensi

1) Akif : :2

2) Pasif : :1

\section{Penilaian (Scoring)}

Scoring adalah menentukan skor atau nilai untuk item pertanyaan dan menentukan nilai terendah dan tertinggi. Jawaban benar diberi skor 1 dan jika jawaban salah diberi skor 0 dengan rumus yang digunakan yaitu menjumlahkan nilai jawaban benar tiap responden kemudian dibagi jumlah kuesioner dikalikan 100\%. Rumusnya :

$$
P=\frac{F}{n} x 100 \%
$$

Keterangan :

$\mathrm{P}=$ Prosentasi

$\mathrm{F}=$ Jumlah jawaban yang benar

$\mathrm{n}=$ Jumlah skor maksimal semua jawaban

(Arikunto, 2002).

$\begin{array}{ll}\text { Baik } & : 76-100 \% \\ \text { Cukup } & : 56-75 \% \\ \text { Kurang } & : 40-55 \% \\ \text { Aktif } & : 60-100 \% \\ \text { Pasif } & :<60 \%\end{array}$

\section{Tabulasi Data (Tabulating)}

Tabulating adalah proses pengelompokan data ke dalam suatu tabel tertentu menurut sifat-sifat yang dimiliki untuk memudahkan analisa data. (Budiarto, 2002).

5. Analisis Data

Analisis data merupakan bagian terpenting untuk mencapai tujuan dimana tujuan pokok penelitian adalah menjawab pertanyaan-pertanyaan peneliti dalam mengungkap fenomena (Nursalam, 2008).

Pada analisis data, peneliti menggunakan uji Koefisien kontingensi untuk mengukur keeratan hubungan antara 2 variabel dengan skala ordinal dan nominal yang bersifat dikotomi (Husaini Usman, 2006 dan Sutrisno, 2005).

Untuk mengetahui hubungan antara variabel dependent dan variable independent. Dalam analisa data ini menggunakan bantuan piranti lunak statistical product and servica solution (SPSS) versi 16.0. dengan tingkat kemaknaan $(\alpha)$ yaitu 0,05 .

Nilai korelasi yang dihasilkan berkisar antara 0 sampai dengan 1 . Angka pada nilai korelasi menunjukkan keeratan hubungan antara 2 variabel yang diuji. Jika angka korelasi makin mendekati 1 , maka korelasi 2 variabel akan makin kuat, sedangkan jika angka korelasi makin mendekati 0 maka korelasi 2 variabel makin lemah.

Keterangan :

1. $100 \%:$ : Seluruhnya

2. $76-99 \%$ : Hampir seluruhnya

3. $51-75 \%$ : Sebagia besar

4. $50 \%$ : Setengahnya atau sebagian

5. 26-49\%: Hampir setengahnya atau hampir sebagian

6. $1-25 \%$ : Sebagian kecil

7. $0 \%$ Tidak satupun 
Adapun rumus untuk menghitung koefisien kontingensi adalah sebagai berikut:

$$
C=\sqrt{\frac{x^{2}}{x^{2}+N}}
$$

Keterangan :

$\mathrm{C}=\quad$ Koefisien kontingensi

$\mathrm{x}^{2}=\quad$ Chi kuadrat

$\mathrm{N}=$ Jumlah populasi

Dengan tingkat kemaknaan adalah $\mathrm{p}$ $\leq 0,05$ artinya bila nilai $\mathrm{p} \leq 0,05$ maka $\mathrm{H}_{0}$ ditolak berarti ada singnifikan atau hubungan yang bermakna antara variabel yang diukur.

\section{HASIL DAN PEMBAHASAN}

\section{Hasil Penelitian}

1. Karakteristik Responden

Berdasarkan Umur

Tabel 1. Distribusi

Responden

Berdasarkan Umur di Desa

Kemlagilor Kecamatan Turi

Kabupaten Lamongan Pada

Bulan Juli 2016

\begin{tabular}{|c|c|c|c|}
\hline No. & Umur & Frekuensi & $\%$ \\
\hline 1. & $\leq 20$ & 2 & 8,3 \\
\hline 2. & $20-35$ & 17 & 70,8 \\
\hline 3. & $36-45$ & 5 & 20,8 \\
\hline & Total & 24 & 100 \\
\hline
\end{tabular}

Dari tabel 1 di atas diketahui sebagian besar responden berumur 20-35 tahun yaitu (70,8 \%) responden dan sebagian kecil berumur $\leq 20$ tahun yaitu $(8,3 \%)$ responden.

\section{Karakteristik Responden}

Berdasarkan Pendidikan

Tabel 2. Distribusi Responden Berdasarkan Pendidikan di Desa Kemlagilor Kecamatan
Turi Kabupaten Lamongan pada bulan Juli 2016

\begin{tabular}{clcc}
\hline No. & Pendidikan & Frekuensi & $\%$ \\
\hline 1. & SD & 3 & 12,5 \\
2. & SMP/Sederajat & 14 & 58,3 \\
3. & SMA/Sederajat & 6 & 25,0 \\
4. & Akademi/Sederajat & 1 & 4,2 \\
\hline & Total & 24 & 100 \\
\hline
\end{tabular}

Dari tabel 2 di atas diketahui sebagian besar responden berpendidikan SMP yaitu $(58,3 \%)$ responden dan sebagian kecil berpendidikan Akademik/Sederajat yaitu $(4,2 \%)$ responden.

3. Karakteristik Responden Berdasarkan Pekerjaan.

Tabel 3. Distribusi Responden Berdasarkan Pekerjaan di desa Kemlagilor Kecamatan Turi Kabupaten Lamongan Pada Bulan Juli 2016.

\begin{tabular}{clcc}
\hline No. & Pekerjaan & Frekuensi & $\%$ \\
\hline 1. & Petani/Wiraswasta & 16 & 66,7 \\
2. & Tidak bekerja/IRT & 8 & 33,3 \\
& & & \\
\hline & Total & 24 & 100 \\
\hline
\end{tabular}

Dari tabel 3 di atas diketahui sebagian besar responden sebagai Petani/wiraswasta yaitu $(66,7 \%)$ responden dan sebagian kecil adalah sebagai ibu rumah tangga biasa $(33,3 \%)$ responden.

\section{Karakteristik Responden} Berdasarkan Motivasi Pada Ibu Nifas Untuk Menyusui Bayinya

Tabel 4. Distribusi Responden Berdasarkan Pengetahuan Pada Ibu Bayi tentang Posyandu di Desa Kemlagilor Kecamatan Turi Kabupaten Lamongan Pada Bulan Juli 2016

\begin{tabular}{clcc}
\hline No. & Pengetahuan & Frekuensi & $\%$ \\
\hline 1. & Baik & 10 & 41,7 \\
2. & Cukup & 11 & 45,8 \\
\hline
\end{tabular}




\begin{tabular}{llrc}
\hline 3. & Kurang & 3 & 12,5 \\
\hline & Total & 24 & 100 \\
\hline
\end{tabular}

Dari tabel 4 di atas diketahui sebagian besar responden mempunyai pengetahuan cukup yaitu $(45,8 \%)$ responden dan sebagian kecil mempunyai pengetahuan kurang yaitu $(12,5 \%)$ responden.

\section{Karakteristik Responden Berdasarkan Frekuensi \\ Kunjungan Bayi di Posyandu.}

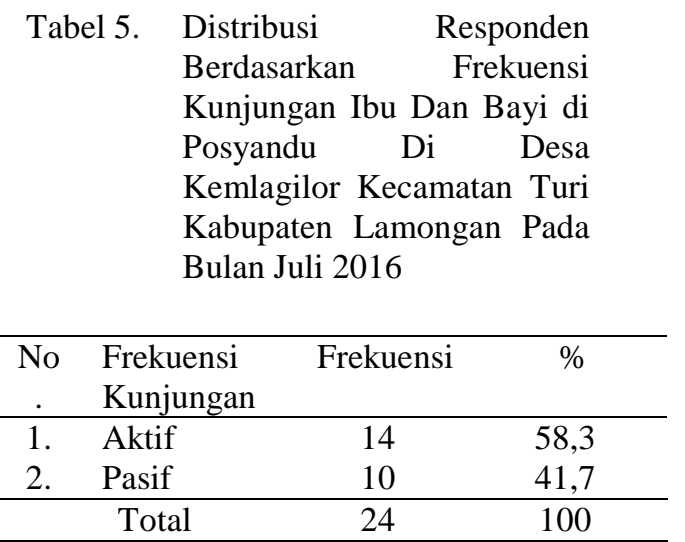

Dari tabel 5. di atas diketahui hampir separuh dari responden pasif dalam kegiatan posyandu yaitu (41,7\%). Dan lebih dari separuh aktif ddalam kegiatan posyandu $(58,3 \%)$.

\section{Hubungan Antara pengetahuan Ibu bayi tentang Posyandu Dengan frekuensi kunjungan ibu dan bayi ke posyandu di Desa Kemlagilor Kecamatan Turi Kabupaten Lamongan}

Dari hasil penelitian diketahui bahwa responden yang mempunyai pengetahuan baik hampir seluruhnya aktif dalam kunjungan di posyandu yaitu $(73 \%)$ responden. Sedangkan responden yang mempunyai pengetahuan kurang hampir semua pasif dalam kunjungan bayi di posyandu yaitu $(100 \%)$ responden.

Dari hasil tabulasi data diatas untuk mengetahui adanya hubungan antara pengetahuan pada ibu bayi tentang posyandu dan frekuensi kunjungan ibu dan bayi dilakukan Uji Statistik dengan menggunakan Koefisien korelasi Kontingensi dengan tingkat kemaknaan $(\alpha)$ yaitu 0,05 . Dalam analisa data ini menggunakan bantuan piranti lunak statistical product and service solution (SPSS) versi 16.0. dengan tingkat kemaknaan $(\alpha)$ yaitu 0,05

Didapat hasil $(\alpha)$ hitung $0.042 \mathrm{Maka}_{0}$ diterima yang artinya Tidak Ada Hubungan Antara Pengetahuan Ibu Bayi Tentang Posyandu Dengan Frekuensi Kunjungan Ibu dan Bayi Ke Posyandu.

.Berdasarkan hasil analisa data jawaban kuisioner dan lembar observasi (Ceklist) dengan menggunakan desain penelitian analitik dengan tarif signifikan 0,05. Untuk mengetahui hubungan antara variabel dependent dan variable independent.

\section{Pembahasan}

\section{Pengetahuan}

Pengetahuan merupakan hasil "tahu" dan ini terjadi setelah orang melakukan pengindraan terhadap suatu objek tertentu. Pengindraan terjadi melalui panca indra manusia, yakni: indra penglihatan, pendengaran, penciuman, rasa dan raba. Sebagian besar pengetahuan manusia diperoleh melalui mata dan telinga. Pengetahuan atau kognitif merupakan domain yang sangat untuk terbentuknya tindakan 
seseorang (overt behavior)

(Notoatmodjo, 2003).

Hasil penelitian menunjukkan bahwa pengetahuan ibu bayi tentang posyandu dengan frekuensi kunjungan ibu dan bayi ke posyandu $(58,3 \%)$ ibu bayi masuk dalam kategori baik.

Hal tersebut juga disebabkan oleh beberapa faktor antara lain umur. Dari tabel 1 hampir sebagian ibu bayi berumur 20-35 tahun yaitu $17(70,8 \%)$ ibu bayi. Pada rentang usia ini kemungkinan pengalaman terhadap aplikasi sehari-hari terlampaui karena semakin cukup usia, tingkat kematangan akan berkembang secara optimal termasuk didalamnya pengalaman serta kekuatan seseorang dalam berfikir dan bekerja (Nursalam dan Siti Pariani, 2001).

Sebagian besar dari ibu bayi berpendidikan SMP $14(58,3 \%)$ ibu bayi, sesuai dengan pendapat Kuncoro Ningrat (1997) semakin tinggi pendidikan seseorang, semakin mudah menerima informasi sehingga semakin banyak pula pengetahuan yang dimilikinya atau sebaliknya.

Hasil penelitian ini menunjukkan bahwa sebagian besar ibu tidak bekerja atau ibu rumah tangga (33,3 \%). Hal tersebut menunjukkan bahwa ibu bayi berperan lebih banyak sebagai ibu rumah tangga, dibandingkan harus bekerja di luar rumah. Dengan demikian diharapkan para ibu lebih mempunyai waktu dalam membawa bayinya ke posyandu, karena ibu yang bekerja lebih sering tidak mempunyai waktu dalam mengurus bayinya seperti yang dikatakan oleh Nursalam (2001) bahwa pekerjaan bukanlah sumber kesenangan tetapi lebih banyak merupakan cara mencari nafkah yang membosankan, berulang dan banyak tantangan dan bekerja pada umumnya menyita waktu. Ibu yang bekerja mempunyai kesibukan yang banyak sehingga tidak mempunyai waktu untuk mengurus bayinya.

\section{Frekuensi Kunjungan Ibu Dan Bayi Ke Posyandu \\ Cakupan Pelayanan Kesehatan Bayi}

Adalah cakupan bayi yang mendapatkan pelayanan paripurna minimal 4 kali yaitu 1 kali pada umur 29 hari-2 bulan, 1 kali pada umur 3-5 bulan, dan satu kali pada umur 6-8 bulan dan 1 kali pada umur 9-11 bulan sesuai sandart di suatu wilayah kerja pada kuru waktu tertentu.

Dengan indicator ini dapat diketahui efektifitas, continum of care dan kwalitas pelayanan kesehatan bayi.

Tabel 6 menunjukkan bahwa frekuensi kunjungan ibu dan bayi ke posyandu $(58,3 \%)$ ibu ibu bayi yang aktif berkunjung ke posyandu, dari ibu bayitersebut semuanya mempunyai pengetahuan baik. Ditinjau dari pendidikan ibu nifas sebagian besar berpendidikan SMP sebanyak $(58,3 \%)$ ibu bayi.

Faktor-faktor yang mempengaruhi kunjungan ibu dan bayi ke posyandu meliputi faktor internal yaitu fisik, psikis, pekerjaan, pengetahuan, keinginan dalam diri sendiri (motivasi), pengalaman. Faktor eksternal yaitu faktor bayi, lingkungan, social budaya dan motivasi dari berbagai pihak baik 
dari keluarga, tetangga maupun dari petugas kesehatan (Handoko, 1998).

Hasil penelitan hampir sebagian responden berumur 20-35 tahun yaitu $22(91,7 \%)$ ibu bayi. Pada rentang usia ini kemungkinan pengalaman terhadap aplikasi seharihari terlampaui karena semakin cukup usia, tingkat kematangan akan berkembang secara optimal termasuk didalamnya pengalaman serta kekuatan seseorang dalam berfikir dan bekerja (Nursalam dan Siti Pariani, 2001).

\section{Hubungan antara motivasi Pada Ibu Nifas Untuk Menyusui Bayinya dengan Kejadian Bendungan ASI Kabupaten Lamongan.}

Penelitian crostab di temukan bahwa ibu yang berpengetahuan baik dan aktif ke posyandu sebanyak 8 responden (73\%). penghitungan Koefisien korelasi kontingensi pada tabulasi data menunjukkan bahwa Ho diterima yang artinya tidak ada hubungan antara pengetahuan ibu bayi dengan kunjungan ibu dan bayi ke posyandu.

Menurut pendapat Sardiman (1996) yang menyatakan bahwa motivasi adalah motif-motif yang menjadi aktif dan tidak perlu dirangsang dari luar karena di dalam diri setiap individu sudah ada dorongan untuk melakukan sesuatu.

\section{KESIMPULAN DAN SARAN}

\section{Kesimpulan}

1. Sebagian besar ibu bayi di posyandu Kemlagi Lor kecamatan Turi kabupaten Lamongan berpengatahuan baik.
2. Sebagian besar frekuensi kunjungan ibu bayi di Posyandu desa Kemlagi Lor kecamatan Turi kabupaten Lamongan adalah aktif.

3. Terdapat hubungan yang signifikan antara pengetahuan ibu bayi dengan frekuensi kunjungan ke Posyandu di desa kemlagi Lor kecamatan Turi kabupaten Lamongan.

\section{Saran}

1. Bagi Keluarga atau Masyarakat

Untuk masyarakat khususnya keluarga untuk selalu memberikan dukungan agar ibu tetap membawa bayinya ke posyandu.

2. Bagi Tenaga Kesehatan

Bagi tenaga kesehatan terutama bidan diharapkan mampu melakukan KIE tentang pentingnya kunjungan ibu dan bayi ke posyandu, sehingga dapat meningkatkan motivasi ibu sebagai orang tua untuk membawa bayinya ke posyandu.

3. Bagi Peneliti Selanjutnya

Hendaknya penelitian ini dapat dijadikan data awal penelitian, untuk dapat dikembangkan lebih luas dan mengambil sampel lebih banyak sehingga hasilnya lebih representatif.

\section{DAFTAR PUSTAKA}

\author{
RI., Depkes. (2006). Penelitian \\ Bendungan ASI. Jakarta. \\ Depkes RI
}
Handoko. (1998), Buku Ajar Keperawatan Maternitas, Jakarta. YBP-SP.


Nursalam, (2003). Konsep dan Penerapan Metodologi Penelitian Ilmu Keperawatan. Salemba Medika. Jakarta.

Nursalam dan Siti Pariani (2001).

Pendekatan Praktis dan Metodologi Riset Keperawatan. Sagung Seto. Jakarta.

Suharsimi Arikunto. (1998). Prosedur Penelitian Suatu Pendekatan Praktek. Jakarta. Rineka Cipta.

Soekidjo, Notoatmodjo. (2005), Metodologi Penelitian Kesehatan. Rineka Cipta. Jakarta.

Soetjiningsih, (1997). ASI : Petunjuk Untuk Tenaga Kesehatan. Jakarta

Kuntoro, Haji. 2007. Metode Statistik. Surabaya, Pustaka Melati 

